\title{
MANAJEMEN KEUANGAN UNTUK MENINGKATKAN PEREKONOMIAN KELUARGA DI MASA PANDEMI COVID-19
}

\author{
Muhammad Ramli ${ }^{1}$, Mulono Apriyanto ${ }^{2}$ \\ ${ }^{1}$ Jurusan Menejemen, Fakultas Ekonomi, Universitas Islam Indragiri, Tembilahan \\ ${ }^{2}$ Jurusan Teknologi Pangan, Fakultas Pertanian, Universitas Islam Indragiri, Tembilahan
}

Email: mulonoapriyanto71@gmail.com (korespondensi)

\begin{abstract}
Money is any object that is generally accepted as payment for goods and services essential to modern civilization. It also serves as an instrument to accumulate wealth and at the same time as an asset to ensure prosperity. The problem in this research is about the study of household financial management according to Islamic teachings. This study uses a qualitative approach with descriptive methods. The analysis technique used is descriptive analysis and content analysis. The results of this study are directed at personal development for the financial management of every Muslim household, developing Islamic financial management, developing the practice of Islamic teachings, especially in the fields of economics and finance, and developing socialization and delivery to others.
\end{abstract}

Keywords: financial management, household, islamic economy

\begin{abstract}
Abstrak
Uang adalah setiap benda yang diterima secara umum sebagai pembayaran atas barang dan jasa yang penting bagi aperadaban modern. Ia juga berfungsi sebagai instrumen untuk mengumpulkan kekayaan dan sekaligus sebagai aset untuk menjamin kemakmuran. Permasalahan dalam penelitian ini adalah seputar kajian tentang pengelolaan keuangan rumah tangga menurut ajaran Islam. Penelitian ini menggunakan pendekatan kualitatif dengan metode deskiptif. Teknik analisis yang digunakan adalah analisis deskriptif dan analisis isi. Hasil penelitian ini diarahkan pada pembinaan kepribadian terhadap manajemen keuangan setiap rumah tangga muslim, pengembangan manajemen keuangan secara Islami, pengembangan pengamalan ajaran Islam khususnya dibidang ekonomi dan keuangan, dan pengembangan sosialisasi dan penyampaian kepada orang lain.
\end{abstract}

Kata kunci: manajemen keuangan, rumah tangga, ekonomi syariah

\section{Pendahuluan}

Masalah utama sebuah keluarga yang selalu ada biasanya seputar keuangan. Bisa karena kekurangan uang, kelebihan uang, atau karena bingung bagaimana mengatur uang bagi orang yang penghasilannya paspasan, sedangkan kebutuhan selalu melebihi pemasukan.

Begitu pentingnya uang dalam peradaban manusia modern, sehingga uang bisa menjadikan orang menjadi bahagia dan juga bisa menjadi sumber malapetaka, sehingga banyak terjadi keluarga menjadi bercerai berai dan muncul masalahmasalah keluarga karena masalah uang [1].

Untuk memenuhi kebutuhan sehari-hari, manusia memerlukan penghasilan. Setiap keluarga tentunya memiliki sumber penghasilan yang berasal dari berbagai bidang pekerjaan yang ditekuninya. Seberapa besar penghasilan dalam suatu keluarga, sebaiknya dapat dikelola secermat dan sebaik mungkin agar pengeluaran sesuai dengan pendapatan yang diterima, sehingga seluruh kebutuhan penting dalam keluarga dapat terpenuhi sesuai kemampuan masingmasing.

Setiap orang berupaya untuk mencapai dambaannya yaitu keluarga yang sejahtera, karena dengan keluarga yang sejahtera yaitu ketika keluarga dapat menikmati hidup yang wajar, terkecukupi kebutuhan materiil 
maupun spiritual dan semua anggota keluarga mendapat kesempatan seluasluasnya untuk berkembang sesuai dengan kemampuan, bakat, dan potensi masingmasing [2].

Gejolak perekonomian yang terjadi akhirakhir ini membuat pusing kepala terutama para ibu rumah tangga yang harus pandaipandai dalam mengelola keuangan. Hal ini karena terjadi akibat naik turun nya harga kebutuhan pokok, meskipun harga BBM turun, tetapi tidak mempengaruhi terhadap turunya harga kebutuhan pokok [3].

Besar kecilnya penghasilan keluarga bukan satu-satunya penentu cukup tidaknya pemenuhan kebutuhan. Penghasilan yang kecilpun bila dikelola (dimanajemen) dengan cermat dan baik akan dapat memenuhi kebutuhan-kebutuhan yang dianggap penting oleh keluarga tersebut. Sebaliknya penghasilan yang besar belum tentu dapat memenuhi semua kebutuhan jika salah atau kurang cermat dalam mengelolanya.

Penelitian ini menggunakan pendekatan kualitatif dengan metode deskiptif. Teknik analisis yang digunakan adalah analisis deskriptif dan analisis isi. Adapun tahap penelitianyang dilalui adalah (1) orentasi, persiapan dan studi pendahuluan (2) Tahap pelaksanaan penelitian yang dilakukan adalah studi literature dan (3) laporan. Hasil penelitian ini diarahkan pada (1) Pembinaan kepribadian terhadap manajemen keuangan setiap rumah tangga muslim, (2) pengembangan manajemen keuangan secara Islami (3) pengembangan pengamalan ajaran Islam khususnya di bidang ekonomi dan keuangan, (4) pengembangan sosialisasi dan penyampaian kepada orang lain.

\section{TINJAUAN PUSTAKA}

\subsection{Keluarga}

Keluarga adalah unit organisasi terkecil yang ada di masyarakat, bahwa keluarga adalah suatu systemnorma dan tata cara yang dit erima untuk menyelesaikan sejumlah tugas penting [4]. Beberapa istilah /definisi tentang keluarga yaitu (1) suatu kelompok yang mempunyai nenek moyang yang sama, ( 2) suatu kel ompok kekerabatan yang disatukan oleh darah atau perkawinan; (3) pasangan perkawinan dengan anak atau tanpa anak.

Komposisi kelompok keluarga pada umumnya di bagi dalam :

1. Conjugal family atau kelurga batih atau nuclear famili , yaitu kel uarga karena pertalian perkawinan atau kehidupan suami istri dan anak atau tanpa anak.
2. Extended family atau keluarga luas yaitu keluarga batih berikut kerabat lain dengan siapa hubungan baik dipelihara

3. Consanguine family yaitu keluarga hubungan sedarah dan tidak berdasarkan pertalian kehidupan suami istri, melainkan pada pertalian darah dari sejumlah orang kerabat.

4. Perkawinan neolokal yaitu pasangan suamiistri tinggal bersama keluarga suami.

5. Perkawinan matril okal, yait u pasangan suami-istri tinggal bersama keluarga istri.

Beberapa istilah /definisi tentang keluarga yaitu (1) suatu kelompok yang mempunyai nenek moyang yang sama, (2) suatu kelompok kekerabatan yang disatukan oleh darah atau perkawinan; (3) pasangan perkawinan dengan anak atau tanpa anak.. Sedangkan menurut( UU RI N0 10 Tahun 1992) Tentang Perkembangan Kependudukan dan Pembangunan Keluarga Sejahtera, bahwa yang dimaksud dengan Keluarga adalah unit terkecil dalam masyarakat yang terdiri dari suami-istri atau suami-istri dan anak atau ayah dan anaknya, atau ibu dan anaknya

\subsection{Manegement Keluarga}

Manusia, finansial, modal fisik dan teknologi adalah jenis-jenis sumber daya organisasi unit bisnis yang perlu dikelola dengan optimal untuk mencapai tujuan organisasi. Manajemen pada dasarnya merupakan proses pemanfaatan sejumlah sumber daya organisasi untuk mencapai tujuan tertentu melalui proses perencanaan, pengorganisasian, pengarahan dan pengendalian.

Dalam mengelola manajemen keluarga, yang bertindak sebagai manajer biasanya adalah ibu rumah tangga. Agar dapat mengelola keuangan keluarga secara professional, keluarga perlu mengetahui beberapa konsep utama tentang manajemen keuangan keluarga.

Ada dua konsep utama tentang manajemen keuangan keluarga yang wajib diketahui oleh keluarga yaitu tentang Neraca dan Rugi/Laba serta Manajemen Cashflow/Arus Kas.

Cashflow atau arus kas adalah aliran uang yang mengalir mulai dari kita mendapatkan uang tersebut, menyimpannya, mengembangkannya, dan mengeluarkannya dengan secara teratur, bijak dan disiplin. Pengetahuan akan cashflow wajib diketahui agar keuangan keluarga kita tidak akan kacau balau dan terpantau. Ada sebuah ungkapan yang cukup menarik "tidak peduli keuangan Anda sedang defisit, yang penting Anda tahu kemana mengalirnya uang 
tersebut."

Penjelasan mengenai diagram cashflow sebagai berikut :

Pertama, Pendapatan. Pendapatan (income) adalah kegiatan yang bertujuan memasukkan uang/harta. Biasanya pendapatan dapat diperoleh dari dua aktivitas, yaitu Gaji dan Investasi. Gaji diperoleh dari status sebagai pegawai/karyawan/professional/konsultan.

Dalam sebuah keluarga gaji ini bisa diperoleh oleh suami dan istri yang bekerjaManajemen keuangan keluarga adalah cara mengatur keuangan keluarga dengan teratur dan cermat melalui tahap perencanaan, pelaksanaan, dan pengawasan / penilaian. Keterampilan manajemen ini sangat penting dimiliki oleh setiap keluarga, karena cukup tidaknya penghasilan keluarga tergantung pada bagaimana cara mengatur ekonomi keluarga.

Kedua, Pengeluaran. Pengeluaran berarti seluruh kegiatan yang mengakibatkan uang berkurang. Dari diagram bisa dilihat banyak sekali kebutuhan akan pengeluaran keluarga. Sehingga bila tidak diatur dengan baik maka bakal membuat keuangan keluarga menjadi kacau dan bila sudah kronis dapat menuju ke jurang kebangkrutan. Secara umum sebuah keluarga memiliki beberapa pengeluaran seperti Pengeluaran Rumah Tangga, Cicilan Utang, Premi Asuransi, Pembantu Rumah Tangga, Keperluan Anak, Transportasi, Zakat/Pajak, Hiburan/Rekreasi, Kegiatan Sosial, Fashion, dan sebagainya.

Ketiga, Catatan atas Laporan Kekayaan dan Laba Rugi. Apabila ada orang yang bertanya, berapa kekayaan bersih Anda saat ini? Berapa persen pertumbuhan kekayaan Anda dibanding tahun kemarin? Berapa laba/surplus pendapatan Anda bulan ini? Berapa persen pertambahan/penurunan laba/surplus pendapatan Anda bulan ini dibanding bulan yang sama pada tahun sebelumnya?, Hampir banyak yang tidak siap memberikan jawaban seketika itu juga. Hal ini dikarenakan kebanyakan dari keluarga tidak memiliki catatan/laporan kekayaan dan laba rugi keluarga kita setiap periode/bulan.

Berbeda halnya di dunia bisnis, setiap periode atau bulan perusahaan memiliki catatan atas laporan kekayaan dan laba rugi perusahaannya. Karena bila perusahaan tidak memiliki laporan tersebut, tentu akan menyulitkan pada pemimpin perusahaan untuk mengetahui posisi finansial perusahaannya, sehingga sangat tidak mungkin dapat mengambil keputusankeputusan bisnis perusahaan.

Tanpa pengetahuan tentang manajemen keuangan, khususnya perencanaan keuangan, maka ekonomi keluarga dapat "kocar-kacir", sehingga kehidupan keluarga menjadi tidak tenteram dan kesejahteraan keluarga tidak tercapai. Bahkan akibat lebih jauh dapat menyebabkan keretakan keluarga. Mengelola keuangan bukan merupakan soal yang mudah dan dapat dikerjakan begitu saja oleh semua orang.

Seperti diketahui bahwa kebutuhan manusia sangatlah banyak, seperti makan, minum, pakaian, tempat tinggal, pendidikan, kesehatan, rekreasi, transportasi, dan sebagainya, sedangkan alat pemuas kebutuhan yang berupa uang jumlahnya terbatas. Hal inilah yang menyebabkan manusia cenderung berkata kurang daripada lebih, karena kurang tahunya mereka bagaimana memanajemen keuangannya.

Melalui manajemen keuangan, kita akan belajar cara mengambil keputusan berdasarkan skala prioritas sesuai kondisi masing-masing keluarga.

Kita dapat memprioritaskan kebutuhan yang sangat penting, penting, dan kurang penting, sehingga harapannya ada uang yang tersisa untuk kebutuhan di masa depan dengan cara menabung.

Management Keuangan Keluarga adalah

"Seni pengelolaan keuangan yang dilakukan oleh individu atau keluarga melalui orang lain untuk mencapai tujuan yang effesien, efektif dan bermanfaat, sehingga keluarga tersebut menjadi keluarga yang sejahtera dan keluarga sakinah [5].

Pengelolaan atau management keuangan keluargamerupakan keharusan yang tidak bisa di tawar lagi, karena me-managemen-i /pengelolaan keuangan keluarga memiliki implikasi yang lebih luas sebab yang terlibat bukan hanya diri sendiri, tetapi istri/suami, anak-anak bahkan mungkin orang tua dan mertua.

Merencanakan keuangan merupakan hal yang penting, terutama bagi keluarga guna mencapai keluarga sejahtera. Disisi lain banyak orang yang tidak memiliki target yg pasti, termasuk dalam perencanaan keuangan dalam upaya mensejahterakan diri dan keluarganya, sedangkan setiap orang memerlukan target yang jelas untuk membantu meningkatkan kesejahterakan keluarga, dengan cara melakukan perencanaan keuangan [2], [4] dan [5].

Perencaan keuangan, adalah suatu proses mengelola uang untuk mencapai tujuan keuangan, tujuan keuangan bagi setiap orang berbeda-beda.,dan yang paling tahu mengenai diri dan tujuan hidup termasuk keuangan adalah diri sendiri.

Perencanaan keuangan keluarga memang tidak berlaku umum, tetapi bersifat spesifik 
yang dipengaruhi oleh faktor-faktor antara lain : status marital, pekerjaan, kondisi ekonomi, usia, asset yang dimiliki, akan tetapi perencanaan keuangan harus di buat se realistis mungkin.

Manajemen dalam keluarga sangat perlu diketahui oleh seorang ibu rumah tangga atau keluarga inti yaitu ayah, ibu,dan anakanak. Mengelola ekonomi keluarga adalah tindakan untuk merencanakan, melaksanakan, memonitor, mengevaluasi, dan mengendalikan perolehan dan penggunaan sumber-sumber ekonomi keluarga agar tercapai tingkat pemenuhan kebutuhan secara optimum, memastikan adanya stabilitas dan pertumbuhan ekonomi keluarga. Manajemen keuangan keluarga salah satunya adalah mengatur pendapatan dan pengeluaran keuangan keluarga [5].

Pendapatan (Income) adalah kegiatan yang bertujuan menghasilkan uang/harta. Biasanya pendapatan dapat diperoleh dari dua aktifitas, yaitu bersumber dari hasil dari pekerjaan berupa gaji dan hasil dari investasi berupa bunga deposito/tabungan, keuntungan kenaikan nilai saham,property, reksadana dll. Kebanyakan keluarga terutama ibu rumah tangga menyimpan seluruh penghasilan yang didapat kedalam bentuk uang tunai, atau disimpan di Bank yang sewaktu-waktudapat diambil di ATM.

Pengeluaran merupakan hal yang perlu diperhatikan yang merupakan suatu aktifitas yang mengakibatkan jumlah harta atau uang kita semakin berkurang karena : pengeluaran rumah tangga, cicilan utang, premi asuransi, pembantu rumah tangga, keperluan anak, transportasi, zakat/pajak, hiburan/rekreasi, kegiatan social, hobby, fashion dan sebagainya [6].

\subsection{Perencnaan dan Pemanfaatan}

Langkah pertama yang harus dilakukan dalam memanajemen keuangan keluarga adalah dengan mendata seluruh masukan pendapatan yang diperoleh keluarga.

Hal ini diperlukan agar kita dapat mengetahui berapa sebenarnya pendapatan keluarga kita per bulannya.

Setelah dicatat total pendapatan tersebut, langkah berikutnya adalah membuat daftar pengeluaran rutin yang harus dikeluarkan setiap bulan, seperti belanja bulanan (gula pasir, sabun, odol, teh, minyak, beras, dil), bayar listrik, air, telepon, pembantu (kalau ada), SPP anak, gas kompor, dan lain-lain. Selanjutnya semua pengeluaran rutin tersebut dijumlahkan.

Langkah selanjutnya, yaitu membuat daftar pengeluaran tidak rutin dengan skala prioritas (urutan pemenuhannya). Jumlahkan seluruh pengeluaran yang ada dalam daftar, kemudian cocokkan dengan total pendapatan yang kita miliki (sudah dikurangi dengan kebutuhan rutin). Jika ternyata pengeluaran yang kita rencanakan melebihi pendapatan yang ada, maka harus diseleksi lagi kirakira pengeluaran mana yang dapat ditunda pemenuhannya.

Setelah ketiga langkah tersebut beres, maka selanjutnya dilakukan evaluasi sebelum rencana tersebut dilaksanakan

Lima langkah-langkah perencanaan sebagai berikut [7]:

1. Perlu diketahui tentang kekayaan bersih yang dimilki (misalnya ; jumlah asset, utang, dan dana yang bisa disisihkan setiap bulan).

2. Menentukan tujuan keuangan(jangka pendek, menengah maupun panjang)

3. Membuat . action plan, (mengalokasikan pendapatan dalam empat hal yaitu konsumsi, saving, investasi dan proteksi)

4. Mengimplementasi plan tersebut secara disiplin.

5. Secara periodik, plan yang telah dibuat dan diimplimentasikan di evaluasi tingkat kesesuaiannya, dan bisa dilakukan perubahan sepanjang ada argumentasi yang jelas.

Pengalokasian dana( dalam arti pendapatan) bulanan di bagi dalam tiga hal pokok yaitu [6]:

1. Konsumsi, pengalokasian ini termasuk pengeluaran biaya tetap (fixed cost) yang tidak bisa di tunda lagi , yaitu : angsuran rumah, angsuran kendaraan, biaya telpon,listrik, dan air , kemudian baru biaya makan, minum, dan rekreasi. Biaya konsumsi ini beragam, akan tetapi perlu di patok atau di tentukan, lazimnya biaya ini berkisar antara $40 \%-50 \%$.

2. Saving atau tabungan, pengalokasian pada tabungan bisa dimaksudkan sebagai simpanan/tabungan tetap dan bisa di maksudkan sebagai tabungan untuk ber jagajaga yaitu misalnya untuk keperluan ke dokter, dan memberi sumbangan. Tabungan ini juga perlu di tentukan dan yang lazim biasanya ber kisar $25 \%$, dari $25 \%$ tersebut yang di gunakan untuk berjaga-jaga ber kisar antara 10\% - $15 \%$, sedangkan sisanya sebagaitabungan tetap.

3. Investasi, pengalokasian pada investasi disini dimaksudkan sebagai pengembang biakan uang tetapi secara terencana dan disiplin. Ada beberapa alternative yandapat dipilih yaitu membeli emas koin, reksa dana atau iuran dana pensiun, maka action plan tentang proteksi dapat dimasukkan dalam pengalokasian pendapat pada investasi 


\subsection{Pelaksanaan Manajemen Keuangan Keluarga}

Dalam melaksanakan rencana pengeluaran yang telah kita susun, maka kita dapat melakukan berbagai model/ sistem, diantaranya :

a. Sistem Amplop

Mengapa disebut sistem amplop ? Ya karena memang sistem ini menggunakan amplop sebagai tempat untuk menyimpan sementara uang kita sesuai dengan kebutuhan yang telah direncanakan. Jadi, uang dibagi-bagi berdasarkan amplopamplop yang telah ditentukan dan ditulis di bagian luarnya.

Hal ini berarti jumlah amplop sesuai dengan jumlah kebutuhan yang telah direncanakan dan disetujui sebelumnya.

b. Sistem Kas Keluarga

Merupakan sistem pembukuan keuangan keluarga yang menekankan pada pembagian pengeluaran menjadi kelompok-kelompok : pengeluaran tetap, harian, dan tak terduga. Semua dicatat secara rinci dalam buku dan setiap jenis pengeluaran dijumlah lalu ditotal dengan pengeluaran jenis lain.

\section{c. Sistem Kas Harian}

Merupakan sistem pembukuan keuangan yang menekankan pada catatan pengeluaran setiap hari. Sistem ini biasa berhasil bila dianut oleh orang yang rajin mencatat apapun yang dikeluarkan setiap hari tanpa malas untuk menulis, meskipun pengeluaran dalam jumlah kecil. Bagi ibu rumahtangga yang menggunakan sistem ini harus secara sabar dan telaten menulis, sebab ketinggalan satu hari saja akan mengacaukan pembukuan berikutnya, sebab

daya ingat orang memang terbatas.

d. Membagi Berdasar Persentase

Bentuk manajemen ini adalah membagi tanggung jawab dalam bentuk jumlah atau persentase seluruh kebutuhan keluarga, setiap bulan dihitung termasuk pos darurat dan pos tabungan. Masing-masing sepakat menyumbang sebesar jumlah tertentu untuk menutupi kebutuhan tersebut. Sisanya digunakan sebagai tabungan pribadi untuk kebutuhan pribadi.

Pada dasarnya penilaian memiliki pengaruh yang baik untuk melihat apa saja yang telah dicapai terhadap pelaksanaan manajemen keuangan yang telah disusun sebagai dasar untuk perbaikan rencana anggaran pada bulan berikutnya. Berdasarkan penilaian ini juga akan diperoleh informasi tentang kelebihan dan kekurangan rencana anggaran kita sehingga dapat diperbaiki atau disempurnakan untuk selanjutnya.

\section{METODOLOGI PENELITIAN}

Penelitian ini diorentasikan untuk mengkaji bagaimana mengelola keuangan dalam sebuah rumah tangga yang Islami. Penelitian ini bersifat kualitatif dengan menggunakan metode deskriptif. Dalam penelitian ini, untuk menemukan teori-teori baku yang digunakan sebagai petunjuk arah dalam menganalisis data yang ditemukan, kemudian dikategorisasi dan ditafsirkan dengan menggunakan perspektif dengan menggunakan analisis dokumenter.

Rekomendasi diarahkan kepada (1) Manajemen keuangan pada setiap rumah tangga muslim tidak akan berhasil secara optimal dan maksimal jika setiap muslim hanya mengetahui ajaran Islam hanya diseputar ibadah mahdhoh saja ( seperti sholat,zakat, 3 puasa, haji, dan mendikotomi Islam dan pengetahuan . (2) perlunya mengetahui bahwa ajaran Islam juga mengajarkan perekonomian, bahkan perekonomian dalam rumah tangga yang islami, (3) perlunya peran serta ulama dan umara agar menerapkan sistem sistem manajemen keuangan secara syariat, dan mendorong berdirinya infrastruktur perekonomian syariah.

Rahasia sukses dalam mengatur keuangan keluarganya dapat ditempuh dengan langkahlangkah sebagai berikut, yaitu:

Pertama, Setiap kali menerima gaji maka langkah awal yang terpenting yang harus dilakukan pertama kali adalah dengan membayar cicilan hutang terlebih dahulu. Karena hutang adalah kewajiban terpenting yang wajib dipenuhi kepada pihak lain apakah dari bank dan institusi finansial lainnya. Kedisiplinan membayar cicilan merupakan cerminan rapor dan nama baik keluarga. Menjaga nama baik sebagai seorang debitor sangat penting, karena akan bermanfaat nantinya di masa yang akan datang. Selain itu pula dengan memprioritaskan membayar cicilan ini, berarti sudah menghargai para kreditor yang sudah berbaik hati meminjamkan uang kepada keluarga.

Kedua. Setelah membayar cicilan hutang, selanjutnya yang dilakukan adalah berzakat atau memberikan sumbangan keagamaan, sebagai salah satu bukti rasa syukur kita kepada Allah SWT. Dia-lah yang telah memberikan karunia rezeki kepada kita semua, sehingga kita bisa melakukan aktivitas ekonomi keseharian dengan lancar tanpa kekurangan. Sehingga Allah SWT akan semakin menambah karunia dan rezeki yang berlimpah kepada kita. 
Ketiga, yang tidak kalah penting adalah menyisihkan minimal $10 \%$ penghasilan untuk ditabung/investasi. Karena, salah satu kebiasaan buruk adalah menunggu kalau ada sisa uang di akhir bulan, padahal kenyataannya hampir selalu tidak ada yang tersisa, itu berarti tidak pernah akan bisa menabung.

Keempat. Langkah terakhir adalah menghabiskan uang gaji atau penghasilan yang tersisa. Baik untuk memenuhi berbagai keperluan rutin keluarga seperti belanja isi dapur, makan, lauk-pauk, asuransi, sekolah anak, rekreasi, beli baju dan sebagainya.

Kemudian disamping kiat di atas ada beberapa hal yang perlu dilakukan dalam keluarga, yaitu: a) Buat perencanaan, baik perencanaan jangka pendek atau perencanaan jangka panjang. Rencana jangka pendek berkaitan dengan kebutuhan saat ini, antara lain biaya hidup sehari-hari hingga keperluan sekolah anak-anak. Rencana jangka panjang dapat diwujudkan dalam bentuk tabungan ataupun aset produktif. b) Berbagi tugas dengan pasangan. Setiap persoalan yang timbul dari pembagian tugas perlu dibicarakan secara jelas dan saling terbuka. Tidak boleh ada rasa saling curiga dan hendaknya bisa diselesaikan bersama-sama. c) Siasati Pengeluaran Ekstra. Pengeluaran perlu diatur sedemikian rupa, dan tetap tidak boleh mengurangi keperluan rumah tangga setiap bulannya.

Rumah tangga memiliki gaya dan pola yang tidak sama dalam hal pengaturan dan sistem pengeluaran keuangan. Tetapi, setidaknya dengan perencanaan ini akan semakin mudah menata manajemen keuangan rumah tangga. Ini akan bermanfaat untuk masa sekarang dan masa datang.

Untuk itu perlu suatu cara yang dapat mengelola keuangan keluarga yang baik. Karena uang seringkali menjadi penyebab terjadinya perceraian. Perselisihan mengenai keuangan bisa saja terjadi disaat uang melimpah maupun disaat kekurangan uang. Masyarakat Indonesia merasa risih bila harus membicarakan masalah keuangan dalam keluarga.

Oleh karena itu perlu semua kalangan masyarakat terutama pasangan suami istri untuk belajar saling terbuka mengenai keuangannya masingmasing. Setiap orang memiliki pandangan mengenai uang yang berbedabeda karena suami atau istri dibesarkan di lingkungan yang berbeda.

Kegagalan dalam membicarakan soal uang di dalam keluarga berpotensi menimbulkan permasalahan.

\section{HASIL DAN PEMBAHASAN}

\subsection{Pengelolaan Keuangan Dalam Rumah Tangga}

Ada tiga hal yang saya anggap kurang tepat dalam pengelolaan keuangan dalam rumah tangga pertama, Pengelolaan keungan dalam rumah tangga dipisahkan dengan ajaran Islam, seolah -olah islam tidak mengajarkan bagaimana cara mengelola keuangan dalam rumah tangga [7], [8]. Kedua Tidak memiliki strategi pengelolaan keuangan dalam Rumah tangga Islami, sehingga sering tidak ditemukan hal-hal yang prinsipil yang seharusnya dipelajari lebih awal, malah terlewatkan, bahkan ini terlebih jelas lagi terlihat implementasi manajemen keuangan dalam rumah tanga yang dianggapnya sebagai puncak atau inti agama, maka islam seakan diidentikan dengan paham keagamaan yang bersifat dikotomi. Ketiga kurangnya penjelasan yang luas dan mendalam serta kurangnya penguasaan simantik dan generik atas istilah istilah kunci dan pokok dalam ajaran agama sehingga sering ditemukan penjelasan yang sangat jauh dan berbeda dari makna yang sebenarnya [1].

Hal semacam inilah yang membuat umat Islam terkadang kaku dalam menjalankan syariat islam, bahkan syariat Islam dianggap suatu hal yang memberatkan ini semua akibat dari cara penyampaian ajaran Islam yang kurang tepat, padahal kalaulah semua umat islam mengetahui bahwa ajaran islam adalah ajaran yang universal yang menyangkut kebahagian dunia dan akherat keselamtan dunia dan akherat, hal inilah sebenarnya yang diinginkan oleh semua orang.

Contoh Pengelolaan keuangan dalam rumah tangga :

Pemasukan /bulan 3.000.000

Pengeluaran :

1. Kebutuhan pokok $50 \%=1.500 .000$

2. Zakat/infak/sodakoh $=75.000$ ( jika zakat, lihat nasab dan khaulnya, jika infak dan sodakoh seikhlasnya

3. Kredit $20 \%=600.000$

4. Investasi $10 \%=300.000$

5. Uang Gawat darurat $71 / 2 \%=225.000$

6. Total pengeluaran $100 \%$

Pada dasarnya mengukur kesehatan keuangan Rumah tangga adalah bagaimana cara kita berkomitmen untuk melaksanakan apa yang telah direncanakan diatas, karena jika kita tidak bisa komitmen terhadap keuangan Rumah tangga, maka keuangan rumah tangga dalam keadaan sakit, jika kita dapat melaksanakan perencanaan keuangan sesuai yang kita 
rencanakan seperti contoh diatas maka keuangan Rumah tangga kita dalam keadaan sehat [9].

Ketika pengeluaran uang melebihi penerimaan uang, maka perlu dilakukan pencarian dana, dan salah satu alternatifnya adalah dengan hutang. Hutang adalah dana dari pihak ketiga yang pada waktu jatuh tempo harus dikembalikan. Hutang memang bisa menjadi dewa penyelamat, tetapi pada waktu lain hutang bisa menjadi awal malapetaka yang akan memporakporandakan keuangan keluarga. Hutang bukan hal yang haram tetapi perlu disiasati dan di sikapi, sehingga tidak akan merusak suatu keluarga [4].

\subsection{Keluarga Sejahtera}

Keluarga adalah institusi terkecil dalam masyarakat, keluarga memiliki pengaruh yg sangat besar terhadap keberhasilan pembangunan sebuah bangsa, hal ini terkait erat dengan fungsi keluarga sebagai wahana pembentukan sumber daya manusia yang berkualitas.

Dalam Undang-Undang No 10 Tahun 1992 dan Peraturan Pemerintah Nomor 21 Tahun 1994 tersebut memberikan rincian tentang pedoman umum Pembangunan Keluarga Sejahtera dalam limatahap yaitu [8]:

1. Keluarga Pra Sejahtera yaitu keluargakeluarga yang belum dapat memenuhi kebutuhan dasarnya (basic needs) secara minimal, seperti kebutuhan akan pangan, sandang, papan, kesehatan dan pendidikan.

2. Keluarga Sejahtera Tahap I yaitu keluargakeluarga yang telah dapat memenuhi kebutuhan dasarnya secara minimal, tetapi belum dapat memenuhi keseluruhan kebutuhan ibadah, makan protein hewani, pakaian, ruang untuk interaksi keluarga, dan keadaan sehat, mempunyai penghasilan, bisa baca tulislatin dan ikut keluarga berencana.

3. Keluarga Sejahtera Tahap II yaitu keluargakeluarga yang disamping dapat memenuhi kebutuhan dasarnya, juga telah dapat memenuhi seluruh kebutuhan sosial psikologisnya, akan tetapi belum dapat memenuhi keseluruhan kebutuhan pengembangannya (developentneeds) seperti kebutuhan untuk peningkatan agama, menabung, berinteraksi dalam keluarga, ikut melaksanakan kegiatan dalam masyarakat dan mampu memperolehinformasi.

4. Keluarga Sejahtera Tahap III yaitu keluarga yang telah dapat memenuhi seluruh kebutuhan dasar, kebutuhan sosial psikologis dan kebutuhan pengembangannya, namun belum dapat memberikan sumbagan (kontribusi) yang maksimal terhadap masyarakat, seperti secara teratur (waktu tertentu) memberikan sumbangan dalam bentuk material dan keuangan untuk kepentingan sosial kemasyarakatan serta berperan secara aktif dengan menjadi pengurus lembaga kemasyarakatan atau yayasanyayasan sosial, keagamaan, kesenian, olah-raga, pendidikan dan sebagainya.

5. Keluarga Sejahtera Tahap III Plus yaitu keluarga-keluarga yang telah dapat memenuhi seluruh kebutuhannya, baik yang bersifat dasar, sosial psikologis maupun yang bersifat pengembangan serta dapat pula memberikan sumbangan yang nyata dan berkelanjutan bagi masyarakat.

\section{KESIMPULAN DAN SARAN}

Memanege keuangan keluarga berarti mengelola semua pendapatan atau penerimaan baik penerimaan rutin (continue) maupun penerimaan insedentil (intermeten) dan pengeluaran rutin (continue) dan pengeluaran insedentil (intermeten).

Kesinambungan kehidupan keluarga menuju keharmonisan menjadi suatu keniscayaan bagi terwujudnya keluarga sakinah. Di antara faktor penting yang menjadi penunjang adalah pemahaman keluarga terhadap manajemen keuangan yang tepat. Masih cukup banyak kondisi keluarga yang rentan gejolak yang diakibatkan ekonomi rumah tangga.

Dengan adanya pemahaman yang baik tentang laporan keuangan keluarga, didukung oleh perencanaan yang baik, pembagian tugas dengan pasangan dan usaha mensiasati pengeluaran ekstra maka rumah tangga dapat melalui masalahmasalah keuangan keluarga dengan solusi yang benar. Hal terpenting adalah saling keterbukaan serta menjalani kehidupan keluarga dengan tanggung jawab bersama

\section{DAFTAR PUSTAKA}

[1] I. L. S. Munthe and R. Y. Sari, "Perbandingan Analisa Neraca Keuangan Sarana Perairan Nelayan Di Kabupaten Bintan Dan Kabupaten Lingga," J. IIm. Akunt. dan Finans. Indones., vol. 4, no. 1, pp. 83-90, 2020.

[2] Rodhiyah, "Manajemen Keuangan Keluarga Guna Menuju Keluarga 
Sejahtera," FORUM: Majalah Pengembangan Ilmu Sosial, vol. 40, no. 1. pp. 28-33, 2012.

[3] M. Apriyanto, "Pelatihan Dan Pendampingan Pengolahan Komoditas Kelapa," J. Pengabdi. DAN Pemberdaya. Masy., vol. 3, no. 2, pp. 179-183, 2019.

[4] A. ARNESIH, "Strategi Manajemen Keuangan Dalam Rumah Tangga (Berbasis Ekonomi Syariah )," Hist. J. Progr. Stud. Pendidik. Sej., vol. 10, no. 1 , pp. 1-11, 2016, doi: 10.33373/his.v1i1.387.

[5] Badrunsyah and S. Cahyono, "Penyuluhan Tentang Manajemen Keuangan Keluarga Di RW 06 Kelurahan Cipayung Jakarta Timur," J. Pelayanan dan Pengabdi. Masy., vol. 3, no. 1, pp. 1-9, 2019.

[6] P. M. Dewi, "Partisipasi Tenaga Kerja Perempuan Dalam Meningkatkan Pendapatan Keluarga," J. Ekon. Kuantitatif, vol. 5, no. 2, pp. 119-124, 2012.

[7] R. A. Adelia Marista Safitri, Dina Rahayuning Pangestuti, "Hubungan Ketahanan Pangan Keluarga Dan Pola Konsumsi Dengan Status Gizi Balita Keluarga Petani (Studi di Desa Jurug Kabupaten Boyolali Tahun 2017)," J. Kesehat. Masy., vol. 5, no. 3, pp. 120128, 2017.

[8] D. Kartikasari and F. Handayani, "Pemenuhan Kebutuhan Dasar Manusia Pada Lansia Demensia Oleh Keluarga," J. Nurs. Stud., vol. 1, no. 1, pp. 175-182, 2012.

[9] L. T. Muharlisiani et al., "Public relations management through management by objective," Int. J. Sci. Technol. Res, vol. 8 , no. $10,2019$. 